\title{
14. CLAY MINERALS OF SEDIMENTS FROM DSDP LEG 49
}

\author{
P.P. Timofeev, N.V. Rengarten, M.A. Rateev, and V.V. Eremeev, Geological Institute of the USSR Academy of Sciences, \\ Moscow, USSR
}

\section{INTRODUCTION}

We studied the clay fraction minerals and their distribution in the sediment sections of Sites 407 and 408, situated between the Reykjanes Ridge and the southeastern shore of Greenland, and Sites 410 and 412 in the Mid-Atlantic Ridge area.

The complex of clay minerals in the relatively young sediments of Leg 49 (lower Miocene to Pleistocene) is characterized by poor associations and uniform distributions . Additionally, the clay fractions of sediments from the northern region are highly enriched in amorphous matter, volcanic glass, or opaline matter of siliceous organic remains.

\section{METHODS}

We studied the clay fraction $(<10 \mu \mathrm{m})$ to determine the composition of pelitic particles. Some mixed-layer silicates were identified by means of $\mathrm{X}$-ray diffractograms obtained with diffractometer "DRON-1," using CuK radiation, (34 $\mathrm{kV}, 20 \mathrm{~mA}$ ). The scanning rate was $2 \%$ minute. The $\mathrm{X}$-ray analysis was performed for three states of each sample: air-dried, saturated with glycerine, and heated at $550^{\circ} \mathrm{C}$. To distinguish the chloritic phase from the kaolinitic phase, the samples were treated with 10 per cent $\mathrm{HCl}$.

Analysis of the clay fraction revealed montmorillonite, dioctahedral hydromica, trioctahedral chlorites, and a mixed-layer mineral with a sharp predominance of swelling layers (up to 80 to $90 \%$ ). These layers are characterized by the following diffraction peaks: 13 to $16.4 \AA$ for the air-dried samples, 18.6 to $19.6 \AA$ for glucolated samples, and 9.93 to $10.0 \AA$ for the heated samples, with visible asymmetry at small angles. The $\mathrm{X}$-ray diffractograms of kaolinite, trioctahedral chlorite, and montmorillonite do not differ significantly from the standard minerals. Along with the clay minerals and amorphous substances, the clay fraction $(<0.01 \mathrm{~mm})$ contains zeolite (phillipsite), feldspars, and quartz.

\section{DISTRIBUTION OF CLAY MINERALS}

The clay minerals are described from bottom to top (Figure 1).

\section{Hole 407}

The lower Miocene and lowermost middle Miocene (Cores 24 to 30 ), tuffaceous sponge foraminiferal nannofossil ooze with abundant dark volcanic glass, are characterized by abundant amorphous glassy matter and an admixture of authigenic montmorillonite.

The clay fraction of the middle Miocene deposits (Cores 20 to 23), calcareous diatomites with fragments of volcanic glass of various composition and of overlying section (Cores
18 and 19) foraminiferal nannofossil ooze, has a montmorillonitic composition, often with phillipsite.

The deposits of the upper Miocene (Cores 6 to 14 and 16 to 17), foraminiferal nannofossil ooze enriched in acid volcanogenic glass, have the same polymineral composition (montmorillonite, hydromica, and chlorite) of the clay fraction. The clay fraction of Cores 6 to 14 is characterized, however, by greater enrichment in vitroclastic material among the clay minerals.

\section{Hole 408}

In the lowermost Eocene and the lowermost middle Miocene (Cores 31 to 34), a tuffaceous sponge-foraminiferal nannofossil ooze with fragments of volcanic glass, the clay fraction is composed of pure montmorillonite, sometimes with phillipsite.

The middle Miocene deposits (Cores 24 to 30) are tuffaceous sponge-foraminiferal nannofossil ooze enriched in dark volcanic glass. Their clay fraction has the same montmorillonitic composition (sometimes with phillipsite) as above, but with a considerable admixture of amorphous volcanic glass of various compositions and biogenic silica.

The clay fraction of the upper Miocene deposits (Cores 17 to 23), nannofossil-foraminifer ooze containing remains of siliceous organisms and fragments of acid volcanic glass, contains abundant amorphous substances (chiefly biogenic opal), with an admixture of montmorillonite and kaolinite. Only in the uppermost layer of this section (Sample 408-17-1, 60-61 cm) does hydromica appear with montmorillonite and kaolinite.

The clay fraction of the Pliocene deposits (Cores 10 to 13), foraminiferal nannofossil ooze with silty material and acid volcanic glass, contains amorphous substances and montmorillonite and hydromica.

The clay fraction of the Pleistocene deposits (Cores 1 to 5) contains foraminifers and unsorted polymictic terrigenous ice-rafted material. Along with amorphous substances and montmorillonite, it contains greater amounts of hydromica and sometimes chlorite in varying proportions.

\section{Hole 410}

In the Miocene deposits (Cores 25 to 36), nannofossil-foraminifer ooze with small rock fragments, the clay fraction is of a polymineral composition. It consists of a heavily swelling montmorillonite-hydromica mixed-layer mineral, hydromica, and an admixture of chlorite and kaolinite.

The lower Pliocene deposits (Cores 17 to 24), foraminiferal-nannofossil ooze with acid glass in some interbeds are characterized by uniform, polymineral composition. The predominant components are a heavily swelling montmorillonite-hydromica mixed-layer mineral, 


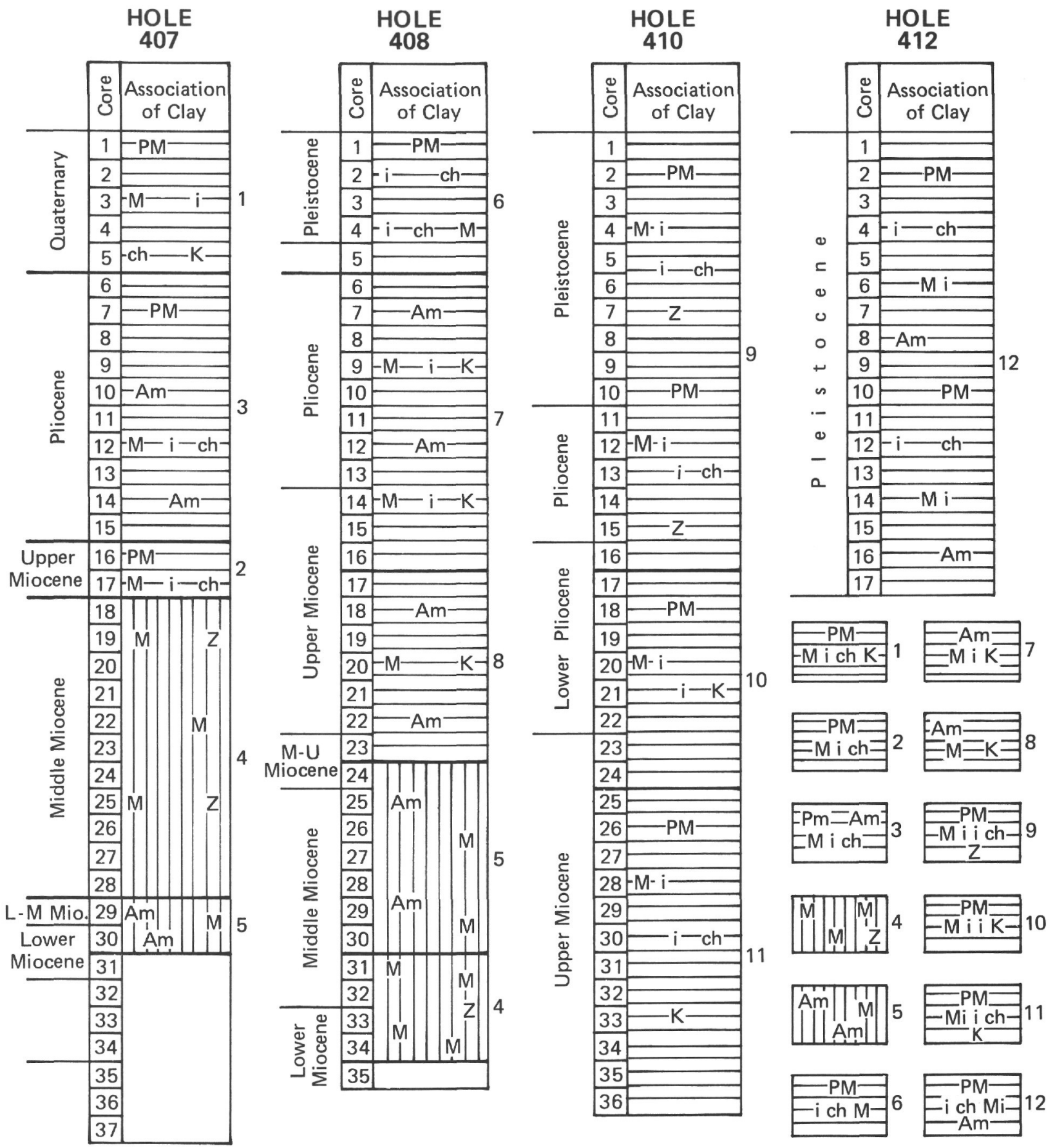

Figure 1. Distribution of clay mineral associations. Symbols: 1 = polymineral hydromica-montmorillonite with chlorite and kaolinite; 2 = polymineral hydromica-montmorillonite with chlorite; $3=$ polymineral with amorphous matter and an admixture of montmorillonite, hydromica, and chlorite; $4=$ montmorillonitic association with zeolite (phillipsite); 5 = amorphous substances with an admixture of montmorillonite; 6 = chloritehydromica with montmorillonite; 7 = polymineral - amorphous substances with an admixture of montmoritlonite, hydromica, and kaolinite; $8=$ amorphous substances with an admixture of montmorillonite and kaolinite; 9 = polymineral hydromica-mixed-layer $(M-i)$ with chlorite; 10 = polymineral hydromica-mixed-layer with kaolinite; 11 = polymineral, hydromica-mixed-layer with chlorite and kaolinite; 12 = chlorite-hydromica with an admixture of mixed-layer mineral of $(M-i)$ type.

hydromica, and chlorite. The swelling mixed-layer mineral disappears only in the uppermost Pleistocene in the interval (Sample 2-1,70-72 cm) where the clay fraction is represented by chloritic-hydromica association.

\section{Hole 412}

Deposits of the entire Pleistocene series (Cores 1 to 14), carbonate-clayey rocks, are characterized by uniform, 
polymineral composition of the clay fraction. The predominant component is hydromica; chlorite occurs in lesser amounts, as does a swelling montmorillonitehydromica mixed-layer mineral. The lower Pleistocene (Cores 9 to 14) is characterized by abundant amorphous matter (volcanic glass).

\section{CONCLUSIONS}

On the whole, the distribution of clay minerals in the sediments drilled during Leg 49 is characterized by the following.

The lower to middle Miocene sections in Holes 407 and 408 are characterized by a pure montmorillonitic composition for the clay fraction, sometimes with phillipsite or abundant amorphous matter (commonly of the vitroclastic type). The montmorillonite, probably authigenic, was formed in situ as a result of the alteration of volcanic glass of basaltic composition.
The upper Miocene through Pleistocene sections in Holes 407,408 and 410 are characterized by an evident polymineral composition of the clay fraction. The clay fraction contains montmorillonite or montmorillonite-hydromica, dioctahedral hydromica, trioctahedral chlorite, kaolinite, and amorphous (chiefly glassy) substances in variable proportions.

Deposits in the upper Miocene-Pliocene interval of Holes 407 and 408, in the northern region, are enriched in volcanic glassy material, whereas coeval rocks from Hole 410 are practically devoid of it. In the upper Miocene-Pliocene sediments of Hole 408, an admixture of kaolinite occurs; in a deeper water hole (407) it is replaced by chlorite. In sediments from Hole 410, the swelling components are a mixed-layer montmorillonite-hydromica mineral. In all holes included in this study, the Pleistocene deposits differ from the underlying ones in having a full predominance of finely dispersed clay minerals (degraded hydromicas, chlorites, kaolinites, etc.) of terrigenous origin, mainly ice-rafted. 